\title{
CHILD LABOR IN THE COAL MINES ${ }^{1}$
}

\author{
By Owen R. Lovejoy, \\ Assistant Secretary of the National Child Labor Committee.
}

The first field investigation conducted by the National Child Labor Committee was among the anthracite mines of Pennsylvania. Facts revealed in the hearings before the commission appointed by President Roosevelt to seek a settlement of the great strike of 1902 led the committee to believe that conditions existed there which would serve not only to illustrate prominent evils of premature child labor in other sections of our country, but also that, once known, would arouse public opinion to give such expression in legislative action as would bring about a higher plane of life in the anthracite region itself. The committee believed a proper educational preparation for American life was possible for the children of the mining district, and this without bringing undue hardship upon the families, and without in any way hampering the legitimate processes of the coal industry.

This investigation, carried on extensively and at different seasons during the past eighteen months, has demonstrated the wisdom of the committee's action. In every part of the region visited child labor was found to exist. No colliery has been visited in which children have not been found employed at ages prohibited by the law of the State. Various estimates have been given of the number of boys under fourteen and under sixteen years employed in and about the hard coal mines of Pennsylvania. The figures have ranged from 6,000 to 12,000 under fourteen years. All of these estimates are generalizations, based upon specific data which may, and may not, be sufficient. Our own estimates are based on the study of a number of boroughs believed to be typical of the region, and have been gathered in co-operation with school officials, mine officers,

1 Address at the Philadelphia session and at the Second Session of the Second Annual Meeting of the National Chlld Labor Committee, Washington, D. C., December 8,1905 .

(293) 
and other citizens interested in the moral aspects of our work. Without entering upon a detailed discussion of the statistics collected, it may be stated that we have estimated not less than 9,000 or 10,000 boys under fourteen years of age in the mines and breakers of the region, while the percentage in one borough investigated, if carried through the entire region, would give a total of 12,800 . By the laws of the State no child under fourteen years of age may be employed at any labor about a coal mine.

Let us not be misunderstood. It is not claimed that there is open and rebellious violation of the laws by the mining companies in the employment of little children. Through defects in the law, sought to be remedied by legislation last year, it was possible for any child of any age, through the perjury of the parent and the pathetic greed of the notary public who would record any kind of falsehood for a fee of twenty-five cents, to secure a certificate alleging him to be fourteen years of age. With this official document a boy might go to the outside foreman at a mine and secure employment if the mine were in need of boys. It is obvious to a man of average discernment that a boy of nine or ten years is not fourteen, and one breaker boss smiled significantly as he said to me last May, "It's queer how all these little fellows who have come to us this spring are just fourteen and were all born on the first of May." At this mine twenty boys were found in a single group, only three of whom were fourteen years old, while a picture was taken of five of the boys, three of whom were nine and two were ten years old. At another mine the following memorandum is found in my field notes: "Here twenty-two boys were interviewed at the noon interval, all of whom admitted they were under fourteen except one Scotch boy (whose age, by the school record, was found to be ten) and one Irish boy of fifteen, who has been out of school and at work for more than six years. Of the others, one was nine (eight by the school record), three were ten, two were eleven, six were twelve, and three were thirteen (although the school record showed one of the thirteen-year-old boys to be eleven.)"

But while these men are certain that they are employing boys younger than the prescribed age, they are not guilty of violation of law, since every boy has come with an official document, issued by authority of this great State, declaring him to be of the legal age for employment. It may be asked whether these men are not hard 
and unfeeling to commit this moral offence, even though shielded by a defective law. The answer is that many of them received their education in the coal breaker in days when school privileges were less available than now. Many frankly affirm their belief that these early years in the coal breaker are better for the boys than the same number of years spent in school. Furthermore, there are many boys so near the legal age as to render detection of fraud by the employer impossible-and if these certificates are accepted by him in one case, he cannot refuse to accept them in all cases. And whether these mine officials approve or disapprove the system, they are employed by the mining company to produce the maximum output at the minimum cost. Their business is not child protection but coal mining, and no commonwealth should place upon men who are directly interested in the evasion of a law, the burden of its enforcement.

By the child labor law which went into effect May I, I905, the chief defects in former laws were removed, documentary evidence of age being required and certain educational standards prescribed. Unfortunately, by the declared unconstitutionality of one section of the law, the whole has been regarded in many sections as inoperative, and extensive investigations in many boroughs, subsequent to May Ist, failed to show any important improvement as a result of the law.

The work of the small boys at the hard coal mines is principally in the breakers. Pictures of little children toiling under heavy burdens and in noisome channels in coal mines are of the past-thanks to an awakened humanity and improved machinery. The chief duties of the few small boys who work inside the hard coal mines to-day are as mule drivers, spraggers, and gate-tenders. Probably a larger percentage of boys are employed inside the mines in the Wyoming Valley than in other parts of the region, because the gaseous condition of the mines in that region requires many doors to regulate the air currents.

In the coal breaker the principal employment of the boys is in picking slate from the coal. Seated on a board laid across the chute in which the coal comes pouring down from the heavy cylinders where it was dumped by the mine cars to be broken into sizes, the little boy regulates the flow of coal by the position of his feet in the chute and picks out the slate and rock as the coal runs past. In the breakers where the coal is cleaned dry, the cloud of dust is so dense that light cannot penetrate, and even on bright days 
the breaker boys are compelled to wear mine lamps in their little caps to enable them to see the coal at their own feet. On sultry days the dust cloud is often seen hanging like a heavy pall above the great coal breaker for an hour after the work of the day is done.

Many coal breakers in the anthracite region no longer clean the coal dry, but have introduced cleaning machinery, and the wet process which greatly improves the conditions of labor for the breaker boys. That all coal breakers might introduce these improvements is generally conceded by coal operators. The improvements have been made, however, only in portions of the coal region in which the coal is so dirty as to render dry-cleaning impossiblenot from consideration for the comfort of the laborers. The machinery for wet cleaning is expensive and it is doubtful whether any coal mining company will voluntarily introduce the improvements unless compelled by the quality of the coal.

While the labor of young boys is most convenient in this department of the process of preparing coal for market, there is nothing in the nature of the work itself which makes it impossible for a larger boy or a man. It is only because of the economy in wages that child labor is so greatly preferred to the work of men, although the young boy appears to endure the labor of sitting bent over a coal chute all day with less fatigue, and can work at a speed alleged to be greater than that of the man.

Much has been said of the extreme danger to boys working in the coal mines and breakers. Probably there has been an exaggerated idea of the dangers. Every reasonable precaution appears to have been taken by most mining companies against danger and loss of life. It is true we occasionally hear of a little boy in the mine run over by a coal car, or kicked to death by a mule, or fatally injured by a piece of falling slate. And in the coal breakers little boys are sometimes ground in the large crushers that break the coal, caught in the wheels or other machinery, or buried in a stream of coal-the death suffered recently by the little boy in Pittston. But few of these accidents occur in the regular routine of the boys' duties. Few, probably, which with forethought and mature judgment-two of the qualities so rare in a small boy-might not have been avoided.

I believe that general statistics will bear out the statement that 
boys working in the coal breakers suffer no more frequently from injury, as compared with the men injured there, than is the case in other industries. A recent study of the reports of factory inspectors in several of our industrial States, shows a remarkable uniformity in the precentage of accidents. We find in the textile mills, foundries, steel and iron mills, glass houses and machine shops employing children that, in proportion to the number of children employed, accidents to children under sixteen years of age are from 250 to 300 per cent. more frequent than to adults. These unfeeling figures present a terrible arraignment of our industrial system. All our boasted protection of home and childhood stands ashamed before the bare fact that, in working out our industrial purposes in America, we subject our little children to a danger nearly three times as great as that incurred by men, instead of throwing about the weak and defenseless those special safeguards invoked by their helplessness-a humane principle recognized as fundamental by nearly every savage tribe in the history of human evolution.

The menace to morals is not less than that to health. The life of the little boy in the coal breaker is exposed to all the rough usage and hardening surroundings which characterize a form of labor requiring a maximum of manual and a minimum of mental exertion. To sit all day over a dusty coal chute, fixing the mind solely on the distinction between a piece of coal and a piece of rock or slate, and in the close company of a group of boys free from the restraints of home or school, is a kind of preparation for a nineyear-old boy from which, it is true, many have emerged to noble and educated manhood, but from which I venture every right-thinking father and mother who reads these words would make all possible sacrifice to shield their own boys. It is unnecessary here to enter upon a discussion of the evils of profanity, obscenity, gambling and various forms of physical intemperance. It is enough to say that the lives of many of the small boys in the coal region are already so tainted by vicious habits that an almost insuperable obstacle to a maturity of virtue and intelligence is presented.

Efforts to restrict such labor of children is opposed, however, on the ground that child labor in the coal region is not the labor of the "American child," but rather the labor of the little ignorant Slav or other foreigner, who is "much better off working 
there than he could possibly be in the country of his nativity-or even in the public school which he cannot appreciate." The reply is that the children who work in the coal mines of this State are not foreigners. They are Americans! They are the children of parents who have been drawn to us from other countries and who are called "foreigners." But the Slavs who migrate to the coal regions are principally young, enterprising people, whose children are born after they are settled here and call this country "home."

In one borough the school enrollment shows these remarkable facts: that of the 3,288 children enrolled only IOI (3 per cent.) are foreign-born Slavs, while 3,I87 are American-born. But 3,165 (4I per cent.) are the children of foreign-born Slavs, and live in homes essentially foreign and un-American. This is typical of many parts of the coal region. Our problem, therefore, is not the problem of the foreign child in an American country, as is often supposed, but the problem of the American child in a foreign country. As American citizens we must demand that the highest protection and the best opportunities of our country shall be given these children already handicapped by the uninspiring influences of home.

The attitude of the mother of one eleven-year-old girl, who was an unwilling truant from school, is significant. She defended herself by saying: "Sadie, no need no more school. She got more school as me already." The duty of the State is clear. The Slav child is the helpless victim of the frugality, ignorance, and industrial instincts of his parents. $\mathrm{He}$ is taken from school at the earliest available age to eke out the family income by a kind of labor that develops brawn but atrophies brain, and the father and mother are blandly unconscious that they are hanging about the neck of their own child a millstone of ignorance and industrial inefficiency which will drag ever heavier, as the awakening forces of our American civilization accelerate the tide of social progress.

It is not true, as often claimed by those who exploit these children, that the Slav child is stolid, unpromising and unfit for any other kind of life than a life of drudgery in a state of ignorance. One interesting school in the anthracite region is attended by pupils who are, in almost equal numbers, children of Slav and of American parents, although the Slav children drop out rapidly after the early grades. The high school of the borough presents this remarkable (298) 
appeal for the education of the Slav child, that although but eleven of the ninety-nine pupils enrolled in the four high school classes last year were Slavs, the honors for scholarship in both the first and second year classes were held by young Lithuanians, while the valedictorian of Class I905 was a young Jewess born in Russia. A new social standard must be caused to prevail in this region. The Slav must be looked upon as something better than a beast of burden, and must be forced to higher levels. Alert and industrious, he will need no further urging, given one generation of compulsory opportunity. His children must be safeguarded by law and institutions against a standard of thought and living which are the racial inheritance of centuries, and made to feel that the highest gifts in the power of our democracy are his birthright.

Our interest in this problem is not principally for the wellbeing of a specific child here and there who is in danger of evil, or accident, or intellectual dwarfing. These individual sufferers from bad conditions may be left, it is assumed, to the kindly care of such reformatory and corrective agencies as are found in nearly every community. Our interest centers in establishing social conditions in these communities that shall prevent such waste of health and character as menaces public progress. The institutions of our democratic civilization are involved. The coal deposits of that small region are rich beyond present computation, but the human life of the region is more valuable. We find good coal so great a convenience that it is regarded as almost indispensable, and those who are devout do not cease to offer up morning and evening prayers to those who own the coal to supply it at a reasonable price. But coal is not essential to us. There are substitutes, even though expensive and inconvenient. There is no substitute for manhood. No fuel will keep the fires burning on the nation's altars save virtue, intelligence, and industrial efficiency.

And were it necessary to employ these little boys of nine and ten years in order to produce coal at a reasonable price-which no intelligent person believes-better mortgage the factory and the farm and the store and the church and the home to pay the coal bill than put a mortgage on the efficiency of the coming generations which may require centuries to lift. 